\title{
Pollen Morphology of A. glutinosa (L.) Gaertner subsp. glutinosa (Betulaceae)
}

\author{
*İginc KIZILPINAR TEMIZER ${ }^{1}$, Zafer TURKMEN ${ }^{2}$ \\ ${ }^{1}$ Giresun University, Vocational Schools of Health Care, Giresun-Turkey \\ ${ }^{2}$ Giresun University Faculty of Science and Arts, Department of Biology \\ Corresponding Author: kizilpinar@gmail.com
}

Geliş Tarihi:18.04.2016

\begin{abstract}
The Betulaceae family includes six genera and these genera are grown naturally in northern hemisphere. The taxa belonging to this family are anemogame. For this reason they produce too much pollen and these pollen have allergic effects. Alnus glutinosa subsp. antitaurica, A. glutinosa subsp. glutinosa, A. glutinosa subsp. barbata, A. orientalis var. orientalis, A. orientalis var. pubescens are the taxa belonging to the genus Alnus growing naturally in Turkey. A. glutinosa are distributed naturally in the Black Sea Region. The pollen of A. glutinosa can cause to pollinosis and allergic symptoms. Determination of palynological features of this taxon will be helpful for aeropalynological, taxonomic and pharmaceutical researches.

Key Words: Alnus glutinosa subsp. glutinosa, Allergic symptoms, Betulceae,-Pollen morphology,
\end{abstract}

\section{A. glutinosa (L.) Gaertner subsp. glutinosa'nın (Betulaceae) Polen Morfolojisi}

\section{Özet}

Betulaceae familyasının kuzey yarım kürede doğal olarak bulunan 6 cinsi bulunmakta ve bunlar çok sayıda polen üreten anemogam bitkilerdir. Betulaceae familyasına ait taksonların polenleri alerjiktir. Alnus'a ait A. glutinosa subsp. antitaurica, A. glutinosa subsp. glutinosa, A. glutinosa subsp. barbata, A. orientalis var. orientalis, A. orientalis var. pubescens taksonları Türkiye'de doğal olarak yetişmektedir. A. glutinosa subsp. glutinosa, Karadeniz bölgesinde doğal olarak yayılış göstermektedir. A. glutinosa polenleri de saman nezlesi ve alerjik rahatsızlıklara neden olmaktadır. Bu taksona ait polen morfolojisinin belirlenmesinin aeropalinoloji çalışmalarına bunun yanı sıra taksonomik ve farmasötik botanik çalışmalarına yardımcı olacağını düşünmekteyiz.

Anahtar Kelimeler: Alerjik rahatsılılk, Alnus glutinosa subsp. glutinosa, Betulceae; Polen morfolojisi

\section{Introduction}

The Betulaceae is a well-defined family with six-genera (Chen, 1994). Alnus is widely distributed in the temperate and cool regions of the northern hemisphere. Its distribution covering a wide area from Europe-to Asia-to Africa, Turkey is the place where the species is most diversified at infraspecific level owing to the variations in climate (Kutluk, 2014a, Kutluk, 2014b). Moreover, in northern, central and eastern Europe, the allergenic significance of the family Betulaceae is based on the fact that the trees are widespread and shed large quantities of windborne pollen, which rapidly release their allergenic substances in the respiratory tract (Hyde, 1972; Gumowski et al., 2000; Piotrowska 2004; WeryszkoChmielewska et al. 2006). Pollen grains of Alnus glutinosa cause allergic symptoms (Aytuğ, 1971; Pehlivan, 1995). Pollen allergy (pollinosis) is a common disease caused by hypersensitivity reaction of the respiratory tract and eye conjunctivae. The allergenic potency of pollen is related to the presence of hydrophilic protein or glycoprotein (antigen) with a molecular mass of $10 \mathrm{kDa}$ to $70 \mathrm{kDa}$, which is resistant to $\mathrm{pH}$ changes and high temperatures, and can cause stronger or weaker allergic reactions in people (Sikora et al., 2013). Atmospheric pollen is investigated by the discipline called Aeropalynology.

In our opinion, determination of the palynological features of the taxon Alnus glutinosa will be helpful in aeropalynological, paleopalynological, taxonomical and pharmaceutical researches.

\section{Material and Methods}

\section{Locality}

Materials of this study were collected in 2016 from Giresun-Güre. Giresun is located in the eastern part of the Black Sea region $\left(40^{\circ} 54^{\prime} \mathrm{K}\right.$ and $\left.38^{\circ} 25^{\prime} \mathrm{D}\right)$. According to the 
grid system applied by Davis (1965-1988), Güre (Giresun) is located in the grid A7 (Figure 1).

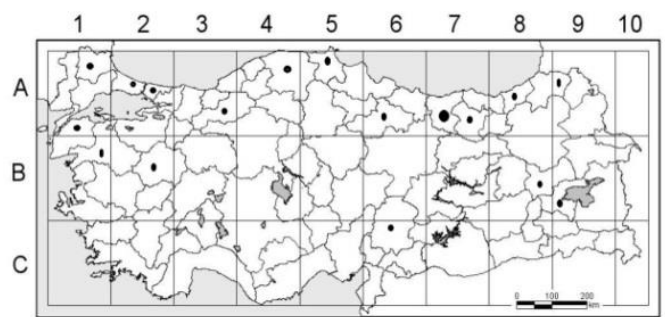

Figure 1. Distribution of A. glutinosa subsp. glutinosa in Turkey

\section{Pollen Sample}

The light microscopy (LM) observations were made on pollen from mature anthers, which have been prepared according to the Wodehouse method (1935). The measurements were taken on 30 pollen grains. Polar axis $(\mathrm{P})$, equatorial diameter (E), diameter of pollen at the polar view (Amb), arci width, annulus width-height, latitude of porus (Plt) were measured from 30 fully developed grains-under the Nikon Eclipse $\mathrm{Ci}$ microscope $(100 \times)$. The minimum, maximum values, mean $+/-$ standard deviations and $\mathrm{P} / \mathrm{E}$ ratios were provided. -Overall grain shape when a pollen grain is lying on its isolpolar axis was assessed as concave, convex or mixed based on the inward curvature of the exine between the pores on pollen grains. All the statistical analyses of the palynological characteristics were made by the SPSS package program. The terminology used is accordance with Erdtman (1969), Kremp (1965) and Punt et al. (2007).

\section{Results and Discussion}

A. glutinosa subsp. glutinosa are widely distributed in the Black Sea region of Turkey (Figure 1). This taxon have the male flowers form an amentum (Figure 2) and constitutes great number of pollen. Pollen is monad, amb polygonal convex, medium-sized, isopolar, suboblate, aperture number 4-5, psilate (Figure 3). Measurements are given in Table 1. Tetragonal pollen grains accounted for $40 \%$ of the total pollen.

Alnus pollen grains are oblate in shape and have protruding aspidate pores along the equatorial plane. Faegri et al. (1989) and Blackmore et al. (2003) defined this feature as stephanoporate and zonoporate, respectively.

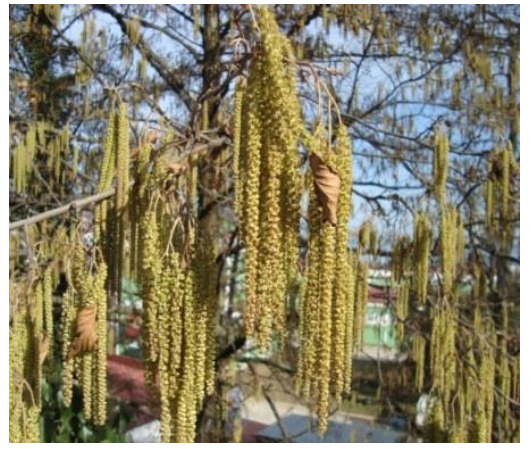

Figure 2. The male flowers of A. glutinosa subsp. Glutinosa
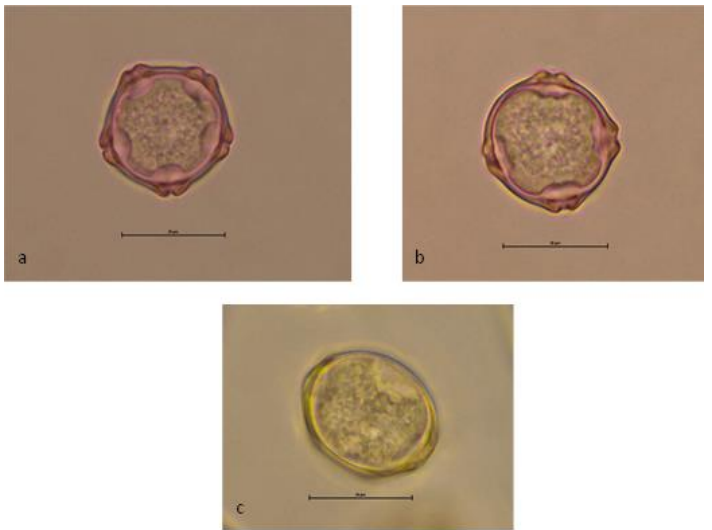

Figure 3. A. glutinosa subsp. glutinosa a-b: polar view; c: equatorial view (scale bar $10 \mu \mathrm{m})$

Table 1. The palynological measurements of A. glutinosa subsp. glutinosa (M: median, Var.: variation, S: standart deviation)

(Measurements are based on 30pollen grains).

\begin{tabular}{ccc}
\hline $\mathrm{P} / \mathrm{E}$ & Suboblate & 0.79 \\
\hline $\mathrm{P}(\mu \mathrm{m})$ & $\mathrm{M}$ & 21.90 \\
& $\mathrm{~S}$ & \pm 1.34 \\
& Var. & $20-24$ \\
\hline $\mathrm{E}$ & $\mathrm{M}$ & 27.86 \\
& $\mathrm{~S}$ & \pm 1.74 \\
$(\mu \mathrm{m})$ & Var. & $25-31$ \\
\hline Annulus & $\mathrm{M}$ & 7.63 \\
& $\mathrm{~S}$ & \pm 1.03 \\
width & Var. & $6-10$ \\
& &
\end{tabular}


Tablo 1 (continued)

\begin{tabular}{cccc}
\hline \multicolumn{2}{c}{ Annulus } & M & 3.19 \\
thickness & S & \pm 0.66 \\
$(\mu \mathrm{m})$ & Var. & $2-4$ \\
\hline Plt & M & 2.62 \\
& S & \pm 0.8 \\
$(\mu \mathrm{m})$ & Var. & $2-4$ \\
\hline Exine & M & 1.83 \\
& S & \pm 0.38 \\
$(\mu \mathrm{m})$ & Var. & $1-2$ \\
\hline Sexine & M & 0.91 \\
& S & \pm 0.19 \\
$(\mu \mathrm{m})$ & Var. & $0.5-1$ \\
\hline Nexine & M & 0.91 \\
& S & \pm 0.19 \\
$(\mu \mathrm{m})$ & Var. & $0.5-1$ \\
\hline Arci & M & 0.8 \\
& S & \pm 0.24 \\
$(\mu \mathrm{m})$ & Var. & $0.5-1$ \\
\hline Amb & M & 26.03 \\
& S & \pm 1.27 \\
$(\mu \mathrm{m})$ & Var. & $24-28$ \\
\hline
\end{tabular}

Aytuğ (1971) described that stephanoporate, suboblate (P/E: 0.85), granulate and the generality four pore $(60 \%)$. These findings are consistent with our study except for percentage of pollen grains based on pore number. Leopod et al. (2012) determined that the morphology of Alnus pollen is unique within the Betulaceae. Ornamentation shows similar characteristics in both Betula and Alnus pollen, such that the sculpture is psilate in surface view based on LM, scabrate under scanning electron microscope (SEM). Zhi-Duan (1991) defined pollen grains of the Tribe Betulaceae (including Alnus and Betula) as triporate, stephanoporate, oblate, suboblate or spheroidal.-The exine may possess an arci and the ektexine thickens in the apertural region; the sculpture of exine is slightly rugulate under SEM; the exine structure is four-layered; tectum, columellae, footlayer and endexine; and columellate; the endexine thickens in the apertural region and sometimes it is separated from the footlayer to form vestibulum. Xiuxia et al. (2006) described the pollen grains as having 4-5 pores, spheroidal or subspheroidal, equatorial view suboblate, polar view quadrilateral or pentagonal in shape, $22.5-35 \mu \mathrm{m}$ in diameter. Under the LM, there are four or five apertures of special configuration such that the sexine and nexine are separated and form a remarkable vestibulum. Under the optical section view, nexine thickens in the apertural region. The ornamentation of the exine is unconspicuously granulate forming lirae. Under the SEM the apertures are of short, with the long axis of $3.2 \mu \mathrm{m}$ in length and the short one $1.5 \mu \mathrm{m}$. Exine is $2 \mu \mathrm{m}$ thick. The ornamentation of the exine is spinulose. In paldat $\left(\mathrm{URL}_{1}, 2016\right)$ the taxon is described as monad, medium-sized $(26-50 \mu \mathrm{m})$, porate, isopolar, oblate, outline in polar view polygonal, oblate shape of dry pollen, outline in polar view polygonal, aperture number 5, stephanoporate, scabrate (LM), rugulate, granulate (SEM), eutectate (TEM), arcus present. Wall shape which was divided into three types of concave, convex and mixed pollen (Shayanmehr et al. 2015). The shape of pollen grains here in this study generally exhibited a convex shape. In the website of geoarizona $\left(\mathrm{URL}_{2}\right)$ Alnus pollen is described as oblate, 20-30 $\mu \mathrm{m}$, stephanoporate (4-5 pores in equatorial plane) with distinctive lines of thickening (arci) joining the pores in both hemispheres. Sculpture scabrate to rugulate. Arci are external and internal. Aforementioned litature review reveals that our palynological results are in accordance with Alnus and A.glutinosa pollen investigations. Pollen grains of A. glutinosa are radially symmetric, isopolar, 4-5 porate, suboblate, psilate (LM).

\section{Acknowledgements}

We would like to thank Giresun University's Scientific Research Unit (Project No. FEN-BAP-A-250414-49) for the financial support.

\section{Appendix}

A. glutinosa subsp. glutinosa: Tree to 20(30) $\mathrm{m}$ tall, with dark brown, fissured bark. Young shoots glutinous, glabrous or \pm tomentose. Leaves obovate to suborbicular or broadly oblong-elliptic, $3.5-13 \times 3-11 \mathrm{~cm}$, retuse, rounded or slightly acute at apex, broadly cuneate at base, biserrate, glabrous 
except for tufts of hairs in axils of veins or pubescent-pilose beneath, with 4-11 pairs of veins; petiole \pm glabrous or tomentose, $0.7-3$ $\mathrm{cm}$. Fruiting catkins $1-1.8 \times 0.6-1.1 \mathrm{~cm}$, distinctly stalked. Twigs, petioles and leaves \pm glabrous. Leaves with 4-8(-9) pairs of lateral veins, obovate to suborbicular, retuse. Caucasia. Euro-Sib. Element (Davis (19651988).

\section{References}

Aytuğ, B., 1971. İstanbul çevresi bitkilerinin polen atlasi. İstanbul Üniversitesi Orman Fakültesi Yayınları. İ̈ Yayın no:1650, OF Yayın No: $174.330 \mathrm{p}$

Blackmore SI., Steinmann JAJ., Hoen PP., Punt W. 2003. Betulaceae and Corylaceae. Review of Palaeobotany and Palynology 123, 7198.

Chen ZD. 1994. Phylogeny and phytogeography of the Betulaceae. Acta Phytotaxonomica Sinica, 32(1), 1-31 (in Chinese with English summary).

Davis PH. 1965. Flora of Turkey and the East Aegean Islands. Vol. 7, 692. Edinburgh, Edinburgh University Press.

Erdtman G. 1969. Handbook of Palynology: Morphology, taxonomy, ecology. Copenhagen, Munksgaard.

Faegri K, Iversen JK, Kaland PE, Krzywinski K.1989.Textbook of pollen analysis. 4th ed. London: Wiley.

Gumowski PI., Clot B., Davet A., Saad S., Hassler H., Dunoyer-Geindre S. 2000. The importance of hornbeam (Carpinus sp.) pollen hypersensitivity in spring allergies. Aerobiologia, $16,83-86$.

Hyde HA. 1972. Atmospheric pollen and spores in relation to allergy. Clin. Allergy, 2, 153-179.

Kremp W. (1965). Morphologic encyclopedia of Palynology. Univ. of Arizona Press Tucson, $263 \mathrm{pp}$

Kutluk H. 2014a. Phenological response of airborne Alnus Mill. pollen to climatic conditions in Turkey and global climatic changes. American International Journal of Contemporary Research, 4(8), 68-80.

Kutluk H. 2014b. The significance of the Betulaceae family in Quaternary: examples from the Golden Horn (İstanbul) and Hazar Lake (Elazı̆ $\breve{g}$ sediments. Biological Diversity and Conservation. 7/1, 94-109.

Leopod EB., Birkebak J., Reinink -Smith L., Jayachandar AP., Narváez P., Zaborac-Reed S. 2012. Pollen morphology of the three subgenera of Alnus. Palynology, 36(1),131-151.
Pehlivan S. 1995. Türkiye'nin Alerjen Pollenleri Atlası. Ankara: Unal Press (in Turkish).

Piotrowska K. 2004. Comparison of Alnus, Corylus and Betula pollen counts in Lublin (Poland) and Skien (Norway). Ann Agric Environ Med, 11, 205-208.

Punt W., Hoen PP., Blackmore S., Nilsson S., Le Thomas A. 2007. Glossary of Pollen and Spore Terminology. Rev Palaeobot Palynol 143: $1-81$.

Shayanmehr F., Jalali SGH., Hosseinzadeh Colagar A., Yousefzadeh H., Zare H. 2015. Pollen morphology of the genus Alnus Mill. in Hyrcanian forests, north of Iran. Applied Ecology and Environmental Research, 13(3), 833-847.

Sikora M., Valek M., Šušić Z., Santo V., Brdarić D. 2013. Tree pollen spectra and pollen allergy risk in the Osijek-Baranja county. Arh Hig Rada Toksikol, 64,115-122.

Weryszko-Chmielewska E., Puc M., Piotrowska K. 2006. Effect of meteorological factors on Betula, Fraxinus and Quercus pollen concentrations in the atmosphere of Lublin and Szczecin, Poland. Ann Agric Environ Med, 13, 243-249.

Wodehouse RP. 1935. Pollen grains. McGraw Hill, New York.

Xiuxia Z., Zhongze Z., Wenge W. 2006. Study on pollen morphology and ecological factors of Alnus trabeculosa. Acta Micropalaeontologica Sinica, 23(4), 419-424.

Zhi-Duan C. 1991. Pollen morphology of the Betulaceae. Acta Phytotaxonomica Sinica, 29 (6), 494-503.

URL ${ }_{1}$ 2016, https://www.paldat.org/

$\mathrm{URL}_{2}$ 2016, http://www.geo.arizona.edu/palynology 